\title{
ASSESSMENT OF THE IMPACT-ECHO METHOD FOR MONITORING THE LONG-STANDING FROST RESISTANCE OF CERAMIC TILES
}

\author{
OCENA METODE IMPACT-ECHO ZA KONTROLO DOLGOTRAJNE \\ ODPORNOSTI KERAMIČNIH PLOŠČIC PROTI ZMRZALI
}

\author{
Michal Matysik, Iveta Plskova, Zdenek Chobola \\ Brno University of Technology, Faculty of Civil Engineering, Institute of Physics, Veveri 331/95, 60200 Brno, Czech Republic \\ matysik.m@fce.vutbr.cz \\ Prejem rokopisa - received: 2014-08-01; sprejem za objavo - accepted for publication: 2014-09-11
}

doi:10.17222/mit.2014.155

\begin{abstract}
The aim of this paper is to evaluate the possibility of using the impact-echo method for monitoring extremely long-term frost resistance of ceramic tiles. Non-destructive testing methods make it possible to sensitively identify the occurrence and development of defects in materials. Impact-echo methods belong to the family of non-destructive testing methods and can be applied in many branches, among others also in civil engineering. To assess the ceramic-tile frost resistance, a new measurement method was developed based on using the acoustic properties of ceramic tiles. Sets of ceramic tiles of the Ia class were analyzed according to the EN $14411 \mathrm{~B}$ standard. The ceramic tiles under investigation were subjected to degradation due to 500 freezethaw cycles in compliance with the relevant EN ISO 10545-12 standard. To verify the correctness of the impact-echo-method results, additional physical properties of the tested ceramic tiles were measured. To analyze the specimen-surface condition, we also used an Olympus LEXT 3100 confocal scanning microscope. It was proved that the impact-echo acoustic method is a sensitive indicator of a structure condition and can be applied to assess the frost resistance of a ceramic cladding element and predict its service life.
\end{abstract}

Keywords: impact-echo, ceramic tiles, frost resistance, confocal microscopy, freeze-thaw cycles

Namen tega članka je oceniti možnosti za uporabo metode Impact-echo za kontrolo ekstremno dolge odpornosti keramičnih ploščic proti zmrzali. Neporušne preiskovalne metode omogočajo selektivno identifikacijo pojava in napredovanja napak $v$ materialu. Metoda Impact-echo pripada skupini neporušnih metod preiskav in je uporabna v mnogih branžah, med drugim tudi v gradbeništvu. Za oceno odpornosti keramičnih ploščic je bila razvita nova merilna metoda, ki temelji na akustičnih lastnostih keramičnih ploščic. Analizirani so bili kompleti keramičnih ploščic kvalitete Ia po standardu EN 14411 B. Preiskovane keramične ploščice so bile izpostavljene degradaciji pri 500 ciklih zamrznitve-odtaljevanja skladno z odgovarjajočim standardom EN ISO 10545-12. Za preverjanje ustreznosti rezultatov metode Impact-echo so bile izmerjene dodatne fizikalne lastnosti keramičnih ploščic. Za analizo stanja površine vzorca je bil uporabljen konfokalni vrstični mikroskop Olympus LEXT 3100. Dokazano je bilo, da je akustična metoda Impact-echo občutljiv pokazatelj stanja konstrukcije in je uporabna za ugotavljanje odpornosti proti zmrzovanju keramičnih ploščic in za napovedovanje trajnostne dobe ploščic.

Ključne besede: Impact-echo, keramične ploščice, odpornost proti zmrzovanju, konfokalna mikroskopija, cikli zmrzovanje-odtaljevanje

\section{INTRODUCTION}

Non-destructive testing methods make it possible to timely identify the occurrence and development of defects in materials and thus ward off a failure or even a breakdown of a structural unit consisting of mechanically or thermally stressed, or corrosion-affected parts. Defect detection, identification and location are the constituents of a diagnosis of an object's technical condition. Impact-echo methods belong to the family of non-destructive testing methods and can be applied in many branches, among others also in civil engineering. ${ }^{1-5}$ To assess the ceramic-tile frost resistance, a new measurement method was designed, based on using the acoustic properties of the tiles. The frost resistance of a ceramic product is its capacity to withstand, under specified conditions, a certain number of freeze-thaw cycles without any induced defects in the glaze or the body. Whether the material is used inside (for example, in refrigerating or freezing plants) or outdoors (rain, snow, ice) it is always exposed to the joint action of frost and water. Water penetrates into the pores and freezes in there. During this transition from the liquid to the solid phase, its volume grows up, resulting in a mechanical stress in the pores, which gives rise to and affects the tension and deformation distribution. Material-integrity defects, such as crevices, cracks, pitting, etc., may occur consequently. The frost may also give rise to the material spalling. ${ }^{6-9}$

\section{EXPERIMENTAL SECTION}

The ceramic tiles under investigation were subjected to freeze-thaw-cycle-based degradation in compliance with the relevant EN ISO 10545-12 standard: Ceramic tiles - Part 12: Determination of frost resistance. ${ }^{10}$

After having been saturated with water, the lining elements were exposed to alternating temperatures of 
$+5{ }^{\circ} \mathrm{C}$ and $-5{ }^{\circ} \mathrm{C}$. The lining elements were exposed to the omnidirectional action of the freeze-and-thaw stress treatment in a total of 500 cycles. The ceramic-tile quality was assessed after the completion of 50,100, 150, 200, 300 and 500 freeze-thaw cycles. Both visual and impact-echo-based analyses of the specimens were carried out.

The impact-echo method makes it possible to detect cracks also in heterogeneous materials. A short-time mechanical impulse is applied to the specimen under test. This impulse propagates throughout the specimen in the form of transversal and longitudinal spherical waves. It also propagates, from the point of its origin, in the form of a surface wave. The transversal and longitudinal waves are reflected on the internal interface (with cracks and defects) or on the external boundary. The response signal therefore carries information of the existence of structural defects. If the test specimen is damaged, energy is dissipated on the defect boundaries. This is reflected in an increased signal attenuation and waveform distortion. The frost-induced damage of the tiles can be assessed on the basis of the signal attenuation and a significant resonance-frequency shift. In our experiments, the response signal was picked up by piezoelectric sensors. The sensor output was fed into the input of a Yokogawa DL1540CL four-channel, eight-bit digital oscilloscope with a GPIB interface. The sampling frequency was $150 \mathrm{MHz}$. Special software, developed for this type of measurement, was used to further process the signal. When locating the sensors on a measured object, the measured body's geometry and acoustic-signal attenuation are taken into account. To ensure a good acoustic transmission, a layer of a suitable medium (such as paraffin jelly, wax, etc.) is laid on between the sensor and the specimen under test. The sensor output signals are amplified, filtered and saved. What follows is an analysis of the recorded signals using a mathematical analysis method called the Fourier transform, which de-

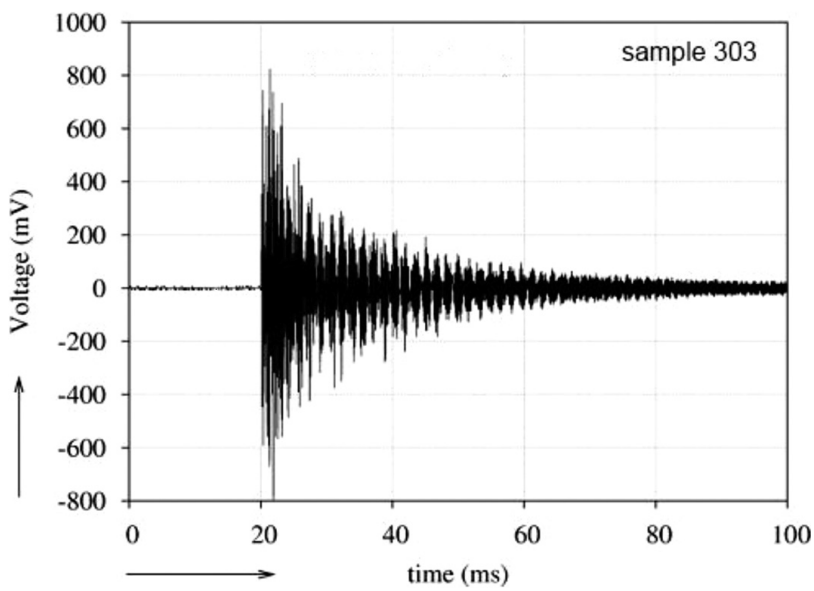

Figure 1: Time-response record for tile number 303, prior to freezethaw cycles

Slika 1: Zapis časovnega odziva ploščice številka 303 pred cikli zmrzovanje-odtaljevanje composes the signals into sine waves of various frequencies and transforms the signal from the time domain into the frequency domain. We look for predominant frequencies in the Fourier spectrum and, particularly, their variations, i.e., their shift towards lower or higher frequencies in each of the load-test stages. Furthermore, it is the coefficient of attenuation $\lambda$ characterizing the exponential drop in the signal amplitudes. The method can be successfully applied for locating cavities and delamination, determining the depth of the open cracks in a surface or measuring a structure thickness. ${ }^{11-14}$

Another important parameter of the ceramic tiles is the modulus of elasticity expressing the capacity of the material in question to undergo elastic or viscous deformations under the influence of an external load. The materials with a high modulus of elasticity feature low deformations; however, heavy tensions are generated in them even by low deformations. It was the objective of our experiments to determine the moduli of elasticity and deformability for the ceramic tiles. The measurements were carried out on intact specimens as well as on the specimens that had undergone 150, 300 and 500 freeze-thaw cycles. The test procedure was carried out in compliance with the ČSN 736174 standard. ${ }^{15-17}$

To determine the strength, elasticity and deformability moduli of the ceramic tiles on the basis of flexural tensile stress tests, a HACKERT/FPZ/100/1 pressing machine was employed. The deflections of each specimen were measured by digital indicators to $0.001 \mathrm{~mm}$.

An Olympus LEXT 3100 laser-type confocal scanning microscope was used to study the surface microgeometry and integrity defects. The microscope uses an Ar laser blue-green spectral line of the wavelength of $488 \mathrm{~nm}$, which makes it possible to attain a very high precision 3D imaging and measurement. The microscope resolution power is as follows: superficial, $120 \mathrm{~nm}$; sectional, $40 \mathrm{~nm}$.

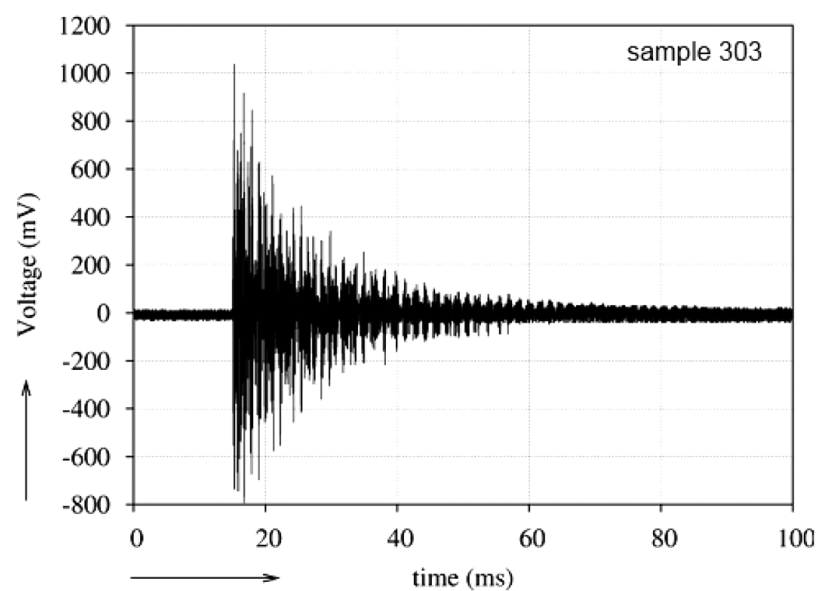

Figure 2: Time-response record for tile number 303, after 500 freezethaw cycles

Slika 2: Zapis časovnega odziva ploščice številka 303 po 500 ciklih zmrzovanje-odtaljevanje 


\section{RESULTS AND DISCUSSION}

Figures 1 and $\mathbf{2}$ show a recording of the time-domain response as picked up at the tile centre of specimen number 303. The measurement was carried out before (Figure 1) and after (Figure 2) the freeze-thaw cycles.

On Figure 3 we can see the power spectral density (in relative unites) versus the frequency plot for specimen number 303 prior to the freeze-thaw cycles. The predominant frequency appears to be $f_{0}=5.4 \mathrm{kHz}$. On Figure 4 we can see the power spectral density for the same specimen after 500 freeze-thaw cycles. The dominant frequency appears to have shifted, being $f_{500}=7.2$ $\mathrm{kHz}$.

Figure 5 shows how the average value of attenuation ratio $\lambda$ changes during 500 freeze-thaw cycles. Figure 6 shows the average value of dominant frequency $f$ during 500 freeze-thaw cycles.

To verify the correctness of the impact-echo results, the ceramic-tile strength limit, the modulus of elasticity and the modulus of deformability were measured by means of the flexural tensile strength test.

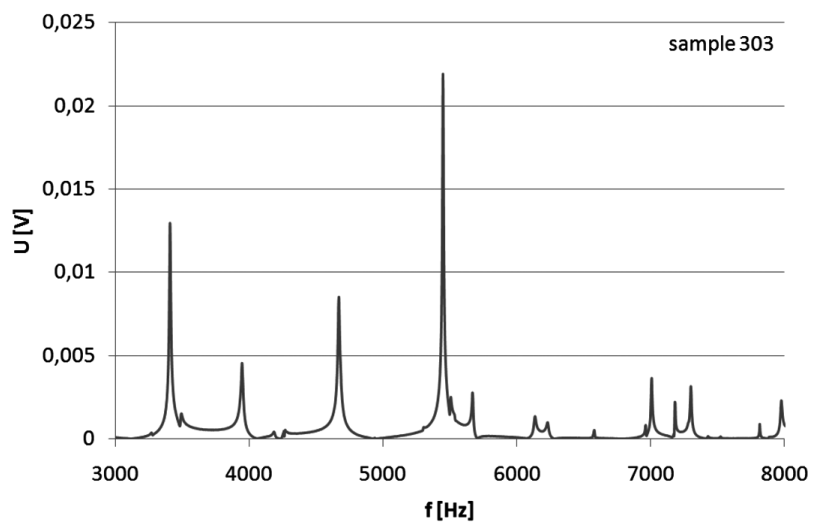

Figure 3: Response frequency spectrum, tile number 303, prior to freeze-thaw cycles

Slika 3: Odgovor frekvenčnega spektra ploščice številka 303 pred cikli zmrzovanje-odtaljevanje

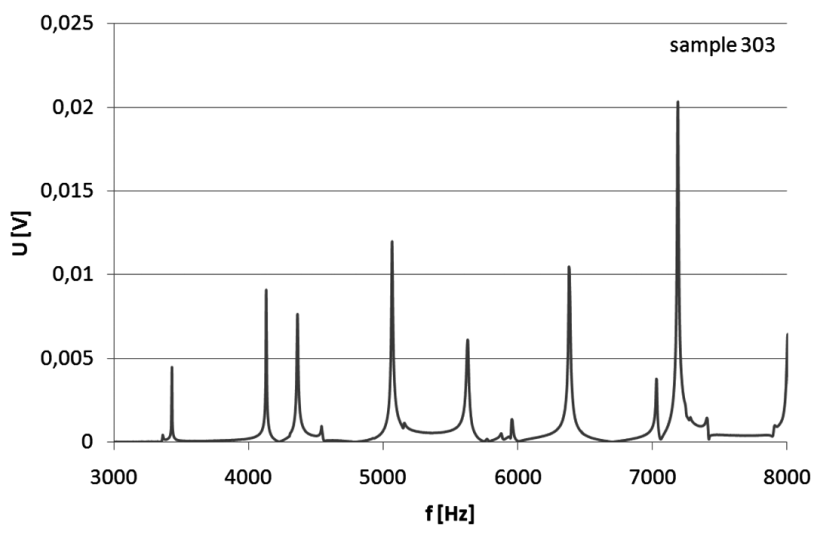

Figure 4: Response frequency spectrum, tile number 303, after a series of 500 freeze-thaw cycles

Slika 4: Odgovor frekvenčnega spektra ploščice številka 303 po seriji 500 ciklov zmrzovanje-odtaljevanje
The ceramic tiles featured the mean tensile strength $R_{\mathrm{tf}}=33.7 \mathrm{MPa}$ prior to the degradation tests and then it dropped to $R_{\mathrm{tf}}=29.2 \mathrm{MPa}$ (by about $13.3 \%$ of the initial value) after the completion of 500 freeze-thaw cycles (Figure 7).

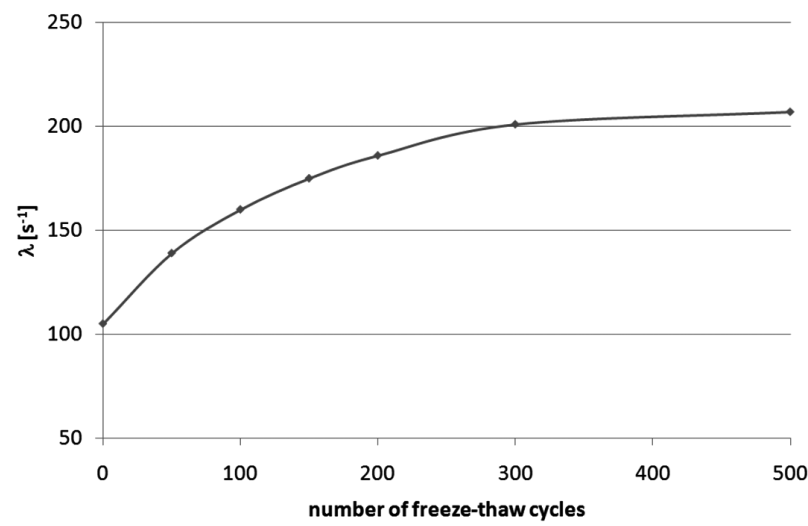

Figure 5: Change in the average value of attenuation ratio $\lambda$ during 500 freeze-thaw cycles

Slika 5: Spreminjanje povprečne vrednosti razmerja slabljenja $\lambda$ med 500 cikli zmrzovanje-odtaljevanje

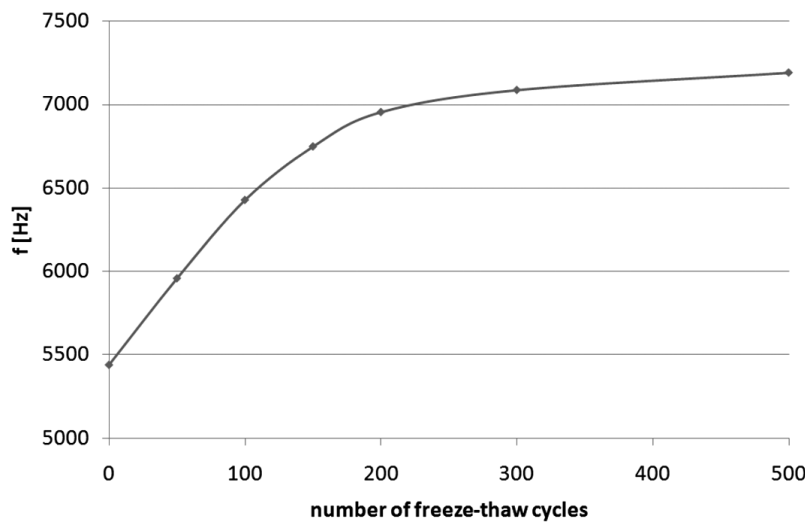

Figure 6: Change in the average value of dominant frequency $f$ during 500 freeze-thaw cycles

Slika 6: Spreminjanje srednje vrednosti prevladujoče frekvence $f$ med 500 cikli zmrzovanje-odtaljevanje

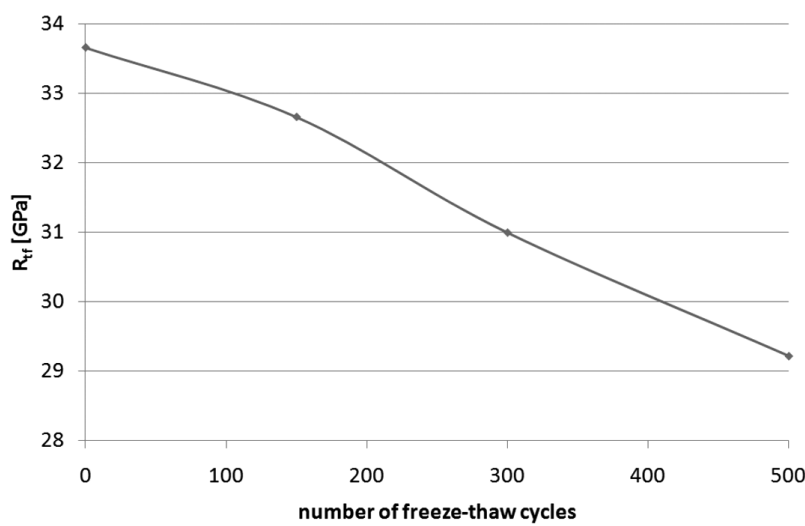

Figure 7: Change in the average value of tensile strength $R_{\mathrm{tf}}$ during 500 freeze-thaw cycles

Slika 7: Spreminjanje povprečne vrednosti natezne trdnosti $R_{\mathrm{tf}}$ med 500 cikli zmrzovanje-odtaljevanje 


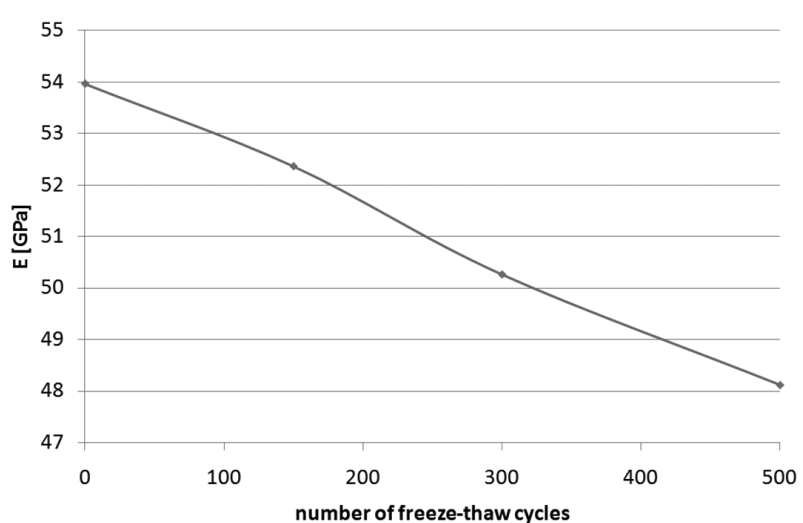

Figure 8: Change in the average value of modulus of elasticity $E$ during 500 freeze-thaw cycles

Slika 8: Spreminjanje povprečne vrednosti modula elastičnosti $E$ med 500 cikli zmrzovanje-odtaljevanje

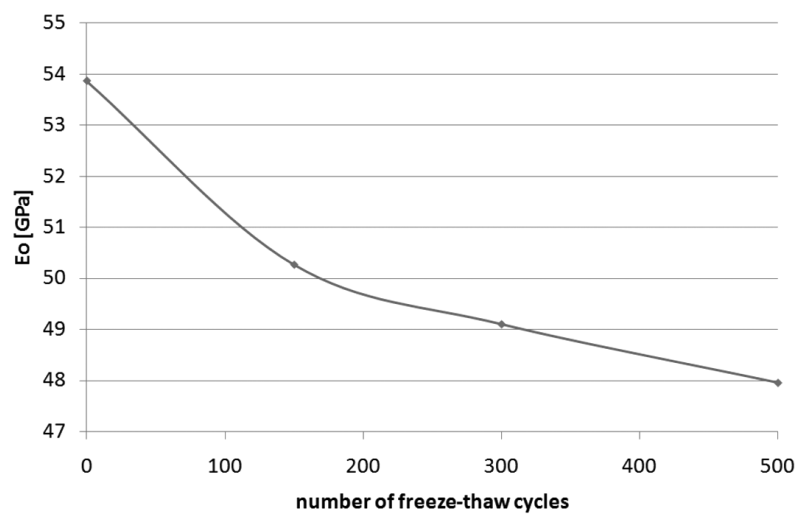

Figure 9: Change in the average value of modulus of deformability $E_{0}$ during 500 freeze-thaw cycles

Slika 9: Spreminjanje povprečne vrednosti modula deformabilnosti $E_{0}$ med 500 cikli zmrzovanje-odtaljevanje

Similarly to the tensile-strength values, moduli of elasticity $E$ also dropped after the application of the freeze-thaw cycles. The average value of modulus of elasticity $E$ of the ceramic tiles dropped from $53.9 \mathrm{GPa}$

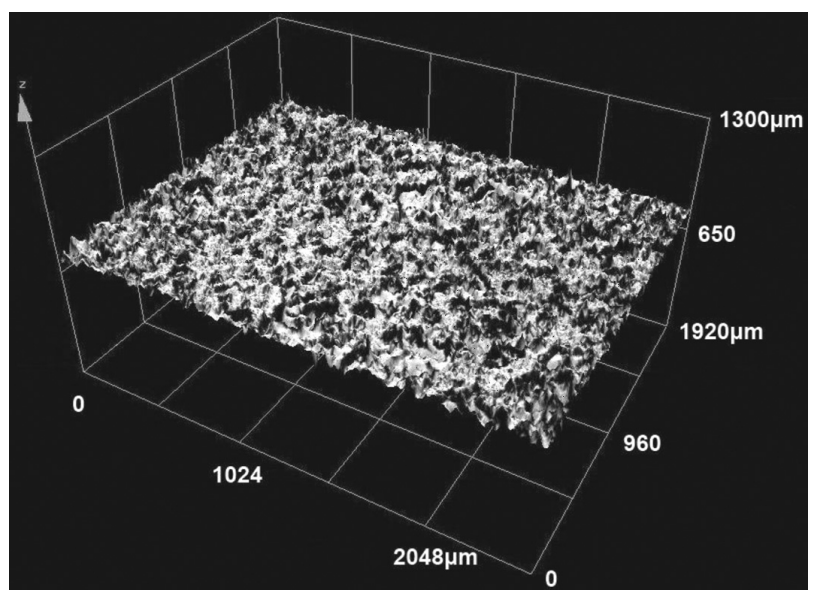

Figure 10: Surface relief before applying the stress test Slika 10: Relief površine pred izvajanjem napetostnih preizkusov

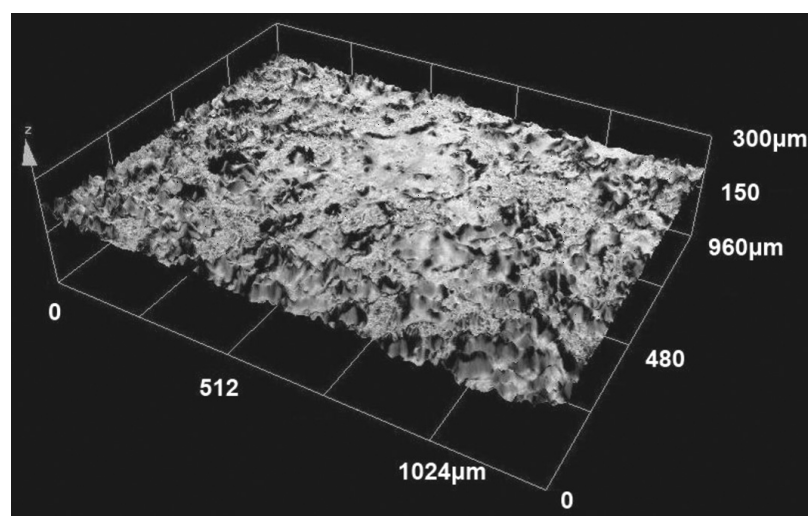

Figure 11: State of the surface after 500 freeze-thaw cycles Slika 11: Stanje površine po 500 ciklih zmrzovanje-odtaljevanje

to $48.1 \mathrm{GPa}$ (by about $10.8 \%$ of the initial value) (Figure 8).

From Figure 9 we can see the change in the average value of modulus of deformability $E_{0}$ during 500 freezethaw cycles.

Using the confocal microscope LEXT 3100, we monitored the state of the surfaces of the ceramic tiles during the degradation caused by 500 freeze-thaw cycles. Figure 10 illustrates the surface relief before applying the stress test. Figure 11 shows the state of the surface after 500 freeze-thaw cycles. We can see that at the beginning the surface roughness was significantly higher and reached the average roughness $R_{\mathrm{a}}=6.9 \mu \mathrm{m}$. Individual peaks covered the surface area of over $60 \mu \mathrm{m}$. After 500 freeze-thaw cycles the roughness decreased to $R_{\mathrm{a}}=$ $4.4 \mu \mathrm{m}$ and individual peaks were not higher than $40 \mu \mathrm{m}$.

\section{CONCLUSIONS}

The present paper deals with the application potential of the impact-echo method to assess and predict the service life of ceramic lining elements and presents the respective results. Sets of 60 ceramic tiles were tested. The ceramic tiles were subjected to degradation tests consisting of 500 freeze-thaw cycles within a temperature interval from $+5{ }^{\circ} \mathrm{C}$ to $-5{ }^{\circ} \mathrm{C}$ and the degradationtest-induced variations in their properties were tracked.

The average value of the dominant frequency during 500 freeze-thaw cycles increased by $33 \%$. To verify the correctness of the impact-echo results, we measured the ceramic-tile strength limit and the modulus of elasticity, resulting from the flexural tensile strength tests. During the degradation tests consisting of 500 freeze-thaw cycles the strength limit decreased by more than $13.3 \%$ and the elasticity modulus decreased by about $10.8 \%$. Using the confocal microscope LEXT 3100 we found that the surface roughness of the ceramic tiles decreased.

The strong correlation between the variations in the classical parameters such as the strength limit, the elasticity modulus and the dominant frequency shifts upward, and the attenuation-coefficient growth also 
convincingly shows that the impact-echo method is a convenient tool for assessing the quality and service life of ceramic tiles. The impact-echo method can also be recommended as a continuous screening tool for automated ceramic-tile production lines.

\section{Acknowledgments}

This research was carried out with the financial support of the European Union's "Operational Programme Research and Development for Innovations", No. CZ.1.05/2.1.00/03.0097, as an activity of the regional Centre AdMaS "Advanced Materials, Structures and Technologies", and with the financial support of the Czech Science Foundation through project GA1318870S and VUT FAST-S-13-2149 No. 23688.

\section{REFERENCES}

${ }^{1}$ H. S. Limaye, R. J. Krause, Materials Evaluation, 49 (1991) 10, 1312-1315, doi:10.1016/S0963-8695(97)88984-0

${ }^{2}$ M. T. Liang, P. J. Su, Cement and Concrete Research, 31 (2001) 10, 1427-1436, doi:10.1016/S0008-8846(01)00569-5

${ }^{3}$ G. Epasto, E. Proverbio, V. Venturi, Materials and Structures, 43 (2010) 1-2, 235-245, doi:10.1617/s11527-009-9484-0

${ }^{4}$ L. Pazdera, L. Topolar, Russian Journal of Nondestructive Testing, 50 (2014) 2, 127-132, doi:10.1134/S1061830914020065

${ }^{5}$ M. Krause, M. Barmann, R. Frielinghaus, NDT \& E International, 30 (1997) 4, 195-204, doi:10.1016/S0963-8695(96)00056-4
${ }^{6}$ D. N. Boccaccini, M. Maioli, M. Cannio, M. Romagnoli, P. Veronesi, C. Leonelli, A. R. Boccaccini, Engineering Fracture Mechanics, 76 (2009) 11, 1750-1759, doi:10.1016/j.engfracmech.2009.03.008

${ }^{7}$ M. Korenska, M. Manychova, L. Pazdera, Russian Journal of Nondestructive Testing, 49 (2013) 9, 530-537, doi:10.1134/ S1061830913090040

${ }^{8}$ E. Cam, S. Orhan, M. Luy, NDT \& E International, 38 (2005) 5, 368-373, doi:10.1016/j.ndteint.2004.10.009

${ }^{9}$ EN 14411:2006 Ceramic tiles - Definitions, classification, characteristics and marking, European Committee for Standardization, Brussels, 2007

${ }^{10}$ EN ISO 10545-12:1997 Ceramic tiles - Part 12: Determination of frost resistance, European Committee for Standardization, Brussels, 1998

${ }^{11}$ K. E. A. Van Den Abeele, A. Sutin, J. Carmeliet, P. A. Johnson, NDT and E International, 34 (2001) 4, 239-248, doi:10.1016/S0963-8695 (00)00064-5

${ }^{12}$ M. Korenska, L. Pazdera, M. Manychova, International Journal of Materials \& Product Technology, 42 (2011) 3-4, 209-218, doi:10.1504/IJMPT.2011.045468

${ }^{13}$ J. J. Wang, T. P. Chang, B. T. Chen, H. C. Lin, H. Wang, Journal of Nondestructive Evaluation, 29 (2010) 2, 111-121, doi:10.1007/ s10921-010-0070-8

${ }^{14}$ T. Ficker, L. Topolar, I. Kusak, Magazine of Concrete Research, 65 (2013) 24, 1480-1485, doi:10.1680/macr.13.00195

${ }^{15}$ CSN 736174 Determination of the modulus of elasticity and modulus of deformation by testing concrete for flexural strength, Czech Office for Standards, Metrology and Testing, Praha, 1994

${ }^{16}$ I. Kusak, M. Lunak, Advanced Materials Research, 897 (2014), 131-134, doi:10.4028/www.scientific.net/AMR.897.131

${ }^{17}$ ISO 4013 Concrete - Determination of flexural strength of test specimens, International Organization for Standardization, Geneva, 1978 